\title{
CREATIVE ENGAGEMENT ON ECOLOGICAL ISSUES: STUDIO WORK EXPERIENCE IN A CONTEXT OF INTERDISCIPLINARY LEARNING
}

\author{
Kyong-Mi PAEK ${ }^{*}$ \\ Ulsan National Institute of Science and Technology, Division of General Studies \\ 50 UNIST-gil, Ulsan 44919, South Korea
}

Received: 3 January 2018; accepted 12 March 2018

\begin{abstract}
The complexity of contemporary environmental issues demands a more holistic and interdisciplinary response. However, despite broad recognition of the educational benefits of interdisciplinary learning contexts, a review of the relevant literature reveals that research interest in the potential of such approaches remains fairly limited and exerts little influence on established pedagogical practices. The paper contributes to the research on interdisciplinary approaches by augmenting empirical understanding of how art can help to promote creative engagement with ecological issues. After describing the process and outcomes of a collaborative ecological art project involving engineering students, the paper reviews some interesting findings from the post-project survey asking about the students' studio work experience. The paper concludes with a discussion of art's potential role in promoting creative engagement in interdisciplinary learning contexts.
\end{abstract}

Keywords: collaborative art project, creative engagement, curriculum development, ecological issues, interdisciplinary learning, practitioner research.

\section{Introduction}

The complexity of contemporary environmental issues has prompted educators to question the validity of the traditional technocentric approach to such problems and to search instead for more holistic approaches that incorporate perspectives from across the disciplines (Clark \& Button, 2011; Curtis, Reid, \& Ballard, 2012; Hadzigeorgiou \& Skoumios, 2013; Jacobson, Seavey, \& Mueller, 2016; Yang, 2015). Susan K. Jacobson, Jennifer R. Seavey and Robert C. Mueller addressed the limitations of conventional university programmes in natural resource management that emphasise scientific understanding of environmental problems and technological solutions:

"Ideally, environmental education should promote interdisciplinary understanding of the natural and built environment through the science, arts, and humanities.

*Corresponding author. E-mail: kpaek@unist.ac.kr 
However, educators focus on technical dissemination of scientific information, or other narrow disciplinary paradigms, which overlooks other ways of understanding the world" (2016, p. 30).

In the same vein, Rachel Gurevitz notes:

\begin{abstract}
"Some critics have argued that an emphasis on scientific understanding of environmental issues offers only a singular, technocentric approach to analysing and solving environmental problems. This approach, in particular, is regarded by some as inherently incapable of engaging citizens in reflecting upon their values or personal behaviour" (2000, p. 255).
\end{abstract}

Young Imm Kang Song has also noted that conventional environmental education for young students includes "an attitude of emotional detachment from nature, an emphasis on a reactive, rather than a preventive, approach, and the limited scope and perspective of environmental education in general" (2008, p. 13). Studies have reported that interdisciplinary approaches enable learners and researchers to explore problems more comprehensively and to think more creatively about solutions by providing opportunities 1) to address learners' behaviours in more environmentally sustainable ways and to take account of their emotions more directly than technocentric approaches (Gurevitz, 2000); 2) to deepen and broaden understanding of human-environment relationships (Clark \& Button, 2011); 3) to increase support for effective communication, public outreach, collective action and behaviour change (Curtis et al., 2012); and 4) to foster environmental awareness by enabling learners "to engage in a wide range of personal, social, economic or political issues that stem from the role of the science have come to play in society" (Hadzigeorgiou \& Skoumios, 2013, p. 406).

These studies contend that the value of an interdisciplinary approach lies in the capacity to create a more socially relevant and personally engaged learning context. According to Stewart J. Hudson, for example, "environmental education [...] must stay relevant to the needs and interests of the community" (2001, p. 283). Emphasising the value of promoting personal connections through integrated learning, Arthur D. Efland (2002) argued that education should enable learners to integrate domains of knowledge into their lifeworld, as any separation of domains causes a loss of meaning or coherence that prevents the learner from connecting new knowledge to what is already known. In particular, Efland argued, "art might serve as an integrating vehicle within the curriculum, since the interpretation of art requires that it be situated in its social and cultural contexts" (2002, p. 105).

Educational researchers have examined the capacity of the arts to engage with ecological issues in creative ways (Bertling, 2015). For example, Douglas Blandy and Elizabeth Hoffman (1993), Cynthia L. Hollis (1997), and Jale Erzen (2005) have explored ways of integrating the diverse concepts and processes of ecological art practice into curricula in order to stimulate students' environmental awareness, sensitivity, and appreciation (see also Inwood, 2010; Neperud, 1997; Song, 2008, 2012; Walker, 2001; Yang, 2015). Over the years, ecological issues have become central to the work of an increasing number of contemporary art practitioners, reflecting their exploration and interpretation of nature, highlighting changes and problems they have observed or, more actively, seeking to promote socio-political change (Brady, 1998; Matilsky, 1992). These ecological art practices are appreciated for their unique capability to communicate local environmental concerns and 
to propose creative solutions to environmental challenges, reaching people in ways that lie beyond scientific practice (Inwood, 2008).

Researchers with a particular interest in scientific innovation have explored diverse ways of integrating art into environmental education that draw on the experiential and interdisciplinary nature of environmental art programs (Clark \& Button, 2011; Curtis et al., 2012; Jacobson et al., 2016; Savva et al., 2004; Song, 2008, 2012). The benefits of art in an interdisciplinary learning context have been identified as 1) "promoting critical inquiry of environmental awareness and sustainability" (Clark \& Button, 2011, p. 42); 2) "enhancing associative and divergent thinking in science students to complement systematic reasoning processes" (Jacobson et al., 2016, p. 30); and 3) "communicating issues, influencing and educating people, and challenging dominant paradigms" (Curtis et al., 2012, p. 3).

A number of empirical studies have explored the potential of art in various educational settings (e.g. Jacobson et al., 2016; Savva et al., 2004; Song, 2012). Andri Savva, Eli Trimis and Aravella Zachariou (2004) designed and executed an in-service teachers' training program to develop participants' environmental perception through artistic activities. They found that artistic activities increased participants' emotional engagement and promoted empathy, an essential component in encouraging environmental awareness. Song's (2012) research project examined the process and outcomes of ecological art projects developed by pre-service and in-service teachers taking a graduate-level course entitled "Environmental Arts and Education". She found that this project-based interdisciplinary approach helped participants to develop a deeper understanding of local environmental issues and concepts, and the use of ecological artworks as resources proved effective as a means of motivating and encouraging creative practice. Jacobson, Seavey and Mueller conducted a case study "to explore the efficacy of an interdisciplinary learning experience integrating science and art students to enhance the curriculum of climate change and potentially other sustainability challenges" (2016, p. 30). Observing learning and communication activities among students during a one-day field trip to a marine lab and analysing their responses to pre- and post-field trip surveys, they identified a number of potential benefits in their integrated science and art project. The context of an informal field trip increased students' interest and motivation, and the integrated approach helped to establish an emotional connection with students, stimulating new dialogues and more creative problem-solving.

The outcomes reported from these experimental studies suggest that integrated art projects can potentially contribute to a more comprehensive understanding of environmental issues and more creative approaches to addressing such problems. However, despite broad recognition of the educational benefits, a review of the relevant literature reveals that research on interdisciplinary learning contexts remains limited, with little impact on established pedagogical practices. The present paper aims to contribute to existing research by augmenting empirical understanding of how art can help to promote creative engagement with ecological issues. To this end, the paper reports a recent collaborative ecological art project involving several groups of engineering students. Data sources included field notes, participant observation, artworks, and students' response to the post-project survey. Outcomes of contextual analyses were organized into two parts: descriptions of the process and outcomes of the projects and a review of the findings of a post-project survey. 


\section{A collaborative ecological art project}

The project was assigned in the spring of 2016 as the final course requirement for undergraduate engineering students taking my Liberal Arts course entitled "Arts and Creativity". As primary instructor, I designed and executed the project with two main objectives: to enhance students' awareness of contemporary ecological issues and to encourage them to go beyond conventional and familiar methods of scientific inquiry to explore alternative approaches.

\subsection{Context: participants and structure}

One hundred and forty-four students participated in the project. They came from a range of academic backgrounds, including energy and chemical engineering, electrical and computer engineering, mechanical and nuclear engineering, materials science and engineering, urban and environmental engineering, natural sciences, life sciences and business administration. Approximately twenty percent of participants were freshmen who had yet to choose their majors. The Liberal Arts course "Arts and Creativity" in this university specialising in science and technology offers engineering students a unique opportunity to explore diverse ideas and practices from the visual arts. Most of the participating students entered the course with little experience of art but were relatively well equipped with the requisite background knowledge by the time they began the final studio project. The course was structured to prepare students for the final project (Table 1).

Table 1. Course structure (source: created by author)

\begin{tabular}{|l|l|l|}
\hline Activity type & \multicolumn{1}{|c|}{ Topic } & \multicolumn{1}{c|}{ Focus of class discussion and group activities } \\
\hline $\begin{array}{l}\text { Topic-based } \\
\text { group study }\end{array}$ & $\begin{array}{l}\text { Topic 1 } \\
\text { Changing views of } \\
\text { creativity and art }\end{array}$ & $\begin{array}{l}\text { This session reviews how concepts of creativity and art have } \\
\text { changed over time and discusses diverse aspects of creative } \\
\text { practices across the different fields today. Follow-up group } \\
\text { activities analyse the lives and works of a few selected } \\
\text { creative practitioners from a sociocultural perspective. }\end{array}$ \\
\cline { 2 - 3 } & $\begin{array}{l}\text { Topic } 2 \\
\text { Cognitive approach } \\
\text { to art learning }\end{array}$ & $\begin{array}{l}\text { This session focuses on visual literacy and helps students to } \\
\text { develop their visual thinking skills. As a follow-up group } \\
\text { activity, students examine a few selected artworks and } \\
\text { engage in a three-step thought exercise: content analysis, } \\
\text { interpretation and reconstruction by re-contextualising } \\
\text { meaning. }\end{array}$ \\
\cline { 2 - 4 } & $\begin{array}{l}\text { Topic } 3 \\
\text { Art \& technology: } \\
\text { extending the } \\
\text { creative space }\end{array}$ & $\begin{array}{l}\text { This session guides students to think about the enduring } \\
\text { relationship between art and science and to explore diverse } \\
\text { art practices arising from the convergence of art and } \\
\text { science. In the group activity, students investigate examples } \\
\text { of how artists incorporate science and technology into their } \\
\text { artworks. }\end{array}$ \\
\cline { 2 - 3 } & $\begin{array}{l}\text { Topic } 4 \\
\text { Ideas and issues in } \\
\text { contemporary art: } \\
\text { cultural identity }\end{array}$ & $\begin{array}{l}\text { This session examines how contemporary artists explore } \\
\text { their social relationships to others by using objects, places } \\
\text { and figures in a symbolic way to represent who they are. In } \\
\text { the group activity, each group explores the characteristics } \\
\text { of their group members and symbolic ways of representing } \\
\text { these characteristics in visual form. }\end{array}$ \\
\hline
\end{tabular}


End of Table 1

\begin{tabular}{|l|l|l|}
\hline Activity type & \multicolumn{1}{|c|}{ Topic } & \multicolumn{1}{c|}{ Focus of class discussion and group activities } \\
\hline Field trip & $\begin{array}{l}\text { Visiting museums or } \\
\text { galleries }\end{array}$ & $\begin{array}{l}\text { This trip requires active participation and thoughtful } \\
\text { responses to on-site art experiences. Students are asked to } \\
\text { report the major features of their experience and creative } \\
\text { aspects of the event, and to suggest ideas for redesigning } \\
\text { what they have experienced, either wholly or in part. }\end{array}$ \\
\hline Studio work & $\begin{array}{l}\text { Collaborative group } \\
\text { art project (various } \\
\text { themes) }\end{array}$ & $\begin{array}{l}\text { This group project requires students to create artworks } \\
\text { by exploring the given themes and developing their ideas } \\
\text { into a two- or three-dimensional structure. The outcomes } \\
\text { are exhibited at a public site on campus such as the library } \\
\text { lobby. }\end{array}$ \\
\hline
\end{tabular}

\subsection{Design of art project}

The format and focus of the final studio project was developed on the basis of student responses to class work in the previous semester. Information collected by means of a post-class survey questionnaire included (1) degree of personal interest in art; (2) degree of personal interest in a convergence project combining art and science; (3) preferred forms of course work; and (4) preferred topics and types of art learning to promote creativity and imagination. The results indicated that science majors had decided to take the course because of a relatively strong interest in the arts and despite their limited knowledge of the area. The data suggest that personal interest in art was a major factor in deciding to take the course, as $81 \%$ of students indicated that their interest in art was higher than average. "Art and Technology" was identified as the most desirable topic, which is perhaps unsurprising, as it reflects science majors' familiarity with technological content. Responses to preferred type of activity also reflected the inclinations of engineering majors, as 63\% indicated a preference for hands-on activities in studio work, particularly developing a three-dimensional object, while only $19 \%$ chose image reading and interpreting (as in Topic 2 ). These survey results informed my design of the project as an interdisciplinary studio piece that would encourage engineering students to incorporate their knowledge of science and technology into threedimensional artworks.

\subsection{Procedure}

Each studio work was executed by four or five engineering students from different majors working together as a group. In order to encourage them to incorporate their knowledge of science and technology into their artwork, the groups were asked "to create an imaginative form of life that contributes to sustainable development". To initiate the group discussion, I introduced the students to the Sustainable Development Goals (SDGs) (UNESCO, 2017) and asked them to consider one of the contemporary environmental issues for development into a group project. Each group selected an environmental problem and gathered information about what had been discussed in order to identify related sociocultural issues and to propose how the issue might be addressed. The group project extended over five weeks and proceeded through four sequential steps: (1) project planning, (2) studio work, (3) presentations and (4) 
exhibition and reflection (see Table 2). To stimulate creative thinking, I set the following, both conceptually and practically challenging tasks: 1) Invent a creature and assign it a role, based on scientific information pertaining to the selected environmental issue. 2) Imagine the life of the creature and give it a backstory. 3) Include some parts of discarded household appliances in your group work. 4) Imagine the creature's movement and consider ways of realising it. For practical reference to possible forms and structures, I reminded students of inspiring kinetic sculptures reviewed in Topic 2 ("Art and Technology") - for example, the works of Theo Jansen and U-Ram Choe, who chart a path between art, science, engineering and cybernetic technologies by creating imaginary forms of life (juxtapoz.com, 2015).

Table 2. Structure of the studioproject (source: created by author)

\begin{tabular}{|l|l|l|l|}
\hline \multicolumn{1}{|c|}{ Step } & Activity type & \multicolumn{1}{|c|}{ Tasks } & Duration \\
\hline $\begin{array}{l}\text { Project } \\
\text { planning }\end{array}$ & $\begin{array}{l}\text { Idea } \\
\text { development }\end{array}$ & $\begin{array}{l}\text { Each group chose one of the contemporary environmental } \\
\text { issues and conducted a small research study on that issue. } \\
\text { Based on what they learned, the students developed an } \\
\text { outline for the group project. }\end{array}$ & 2 weeks \\
\cline { 2 - 4 } & $\begin{array}{l}\text { Draft } \\
\text { presentation }\end{array}$ & $\begin{array}{l}\text { Each group shared their ideas in a five-minute in-class } \\
\text { presentation. In presenting their project plans, groups were } \\
\text { asked to complete the following tasks: 1) invent a creature } \\
\text { and give it a role based on relevant scientific information } \\
\text { pertaining to the environmental issue selected; 2) imagine } \\
\text { the life of the creature and give it a backstory; 3) include } \\
\text { some parts of discarded household appliances; 4) imagine } \\
\text { the creature's movement and consider ways of realising it. }\end{array}$ & \\
\hline Studio work & Creation & $\begin{array}{l}\text { Each group continued to develop more detailed work } \\
\text { plans, collecting materials (including discarded household } \\
\text { appliances) and disassembling and rearranging the parts. }\end{array}$ & 2 weeks \\
\cline { 2 - 4 } & $\begin{array}{l}\text { Progress } \\
\text { report and } \\
\text { feedback }\end{array}$ & $\begin{array}{l}\text { Each group reported on what they had done and what } \\
\text { remained to be done. Discussion and feedback focused } \\
\text { mainly on parts that could be reconsidered to improve the } \\
\text { quality of the project or to highlight its intended meaning. }\end{array}$ & \\
\hline Sharing & $\begin{array}{l}\text { Final } \\
\text { presentation }\end{array}$ & $\begin{array}{l}\text { Each group presented the overall process and final } \\
\text { outcome of their group project, including their personal } \\
\text { reflections. Discussion centred on effective ways of } \\
\text { displaying the project outcomes in the exhibition. }\end{array}$ & \\
\hline $\begin{array}{l}\text { Exhibition } \\
\text { and } \\
\text { reflection }\end{array}$ & $\begin{array}{l}\text { Installation } \\
\text { and surveys }\end{array}$ & $\begin{array}{l}\text { Each group brought their finished work to the exhibition } \\
\text { hall and installed it. Post-class survey questionnaires were } \\
\text { distributed to the students, and responses were returned via } \\
\text { email. }\end{array}$ & 1 week \\
\hline
\end{tabular}

\subsection{Project outcomes}

In developing their project, depending on collective interests and preferences, some groups paid more attention to content development (i.e. the environmental issues) while others focused more on their work's kinetic mechanism or structure (e.g. collection, disassembling and repurposing of household appliances). Table 3 lists the key aspects of five selected group projects (from a total of twenty-seven). Final outcomes were displayed in the lobby of the library for one week (Table 4). 
Table 3. Descriptions of five group projects (source: created by author)

\begin{tabular}{|c|c|c|c|c|}
\hline Group & $\begin{array}{c}\text { Selected environmental } \\
\text { issue }\end{array}$ & $\begin{array}{l}\text { Habitat/Lifestyle/ } \\
\text { Assigned role of } \\
\text { creature }\end{array}$ & Source of energy & $\begin{array}{l}\text { Images of final } \\
\text { outcome }\end{array}$ \\
\hline A & $\begin{array}{l}\text { Soil acidification has } \\
\text { been accelerated by the } \\
\text { use of chemical fertilizers } \\
\text { that reduce the amount } \\
\text { of nutrients recycled by } \\
\text { micro-organisms. }\end{array}$ & $\begin{array}{l}\text { Living in acidic soils, } \\
\text { its digestive organ pro- } \\
\text { duces alkaline fluids. It } \\
\text { reduces levels of toxic- } \\
\text { ity by eating acidified } \\
\text { soils and excreting } \\
\text { neutralised soils. }\end{array}$ & $\begin{array}{l}\text { Acidified soils } \\
\text { are used as a } \\
\text { source of energy. }\end{array}$ & \\
\hline B & $\begin{array}{l}\text { Fine dust pollution has ad- } \\
\text { verse effects on humans and } \\
\text { on the ecosystem. In recent } \\
\text { years, this has become a } \\
\text { serious problem, with in- } \\
\text { creased industrial pollutants } \\
\text { contained in the dust. }\end{array}$ & $\begin{array}{l}\text { This flying creature } \\
\text { reduces the } \\
\text { concentration of fine } \\
\text { dust in the air in } \\
\text { industrial areas such } \\
\text { as Tianjin in Hebei, } \\
\text { China. }\end{array}$ & $\begin{array}{l}\text { Solar panels are } \\
\text { installed on its } \\
\text { wings. }\end{array}$ & \\
\hline $\mathrm{C}$ & $\begin{array}{l}\text { The rapid inflow of } \\
\text { microplastics causes } \\
\text { harmful physical and } \\
\text { chemical effects in the } \\
\text { marine environment. }\end{array}$ & $\begin{array}{l}\text { Living in the sea, it } \\
\text { reduces microplastic } \\
\text { pollution. The bacteria } \\
\text { living in its stomach } \\
\text { break down the } \\
\text { drifting microplastics. }\end{array}$ & $\begin{array}{l}\text { Microplastics are } \\
\text { used as a source } \\
\text { of energy. }\end{array}$ & \\
\hline $\mathrm{D}$ & $\begin{array}{l}\text { Algae causes water } \\
\text { pollution by creating } \\
\text { oxygen-poor "dead-zones" } \\
\text { in the water. }\end{array}$ & $\begin{array}{l}\text { Living in rivers, it } \\
\text { gathers the green } \\
\text { algae, which it uses to } \\
\text { make biofuel. }\end{array}$ & $\begin{array}{l}\text { Green algae are } \\
\text { used as a source } \\
\text { of energy. }\end{array}$ & \\
\hline $\mathrm{E}$ & $\begin{array}{l}\text { The spread of the Zika } \\
\text { virus by mosquitoes } \\
\text { threatens human life. } \\
\text { Outbreaks of the virus } \\
\text { have been recorded in } \\
\text { Africa, the Americas, Asia, } \\
\text { and the Pacific. }\end{array}$ & $\begin{array}{l}\text { Living in tropical } \\
\text { swamps, ponds, and } \\
\text { lakes, it eats Zika virus- } \\
\text { transmitting mosqui- } \\
\text { toes by means of a UV, } \\
\text { LED-based mosquito } \\
\text { trap inside its mouth. }\end{array}$ & $\begin{array}{l}\text { An attached } \\
\text { solar cell } \\
\text { auto-generates } \\
\text { electricity. }\end{array}$ & \\
\hline
\end{tabular}

Table 4. Final projects displayed in the exhibition hall (source: created by author)

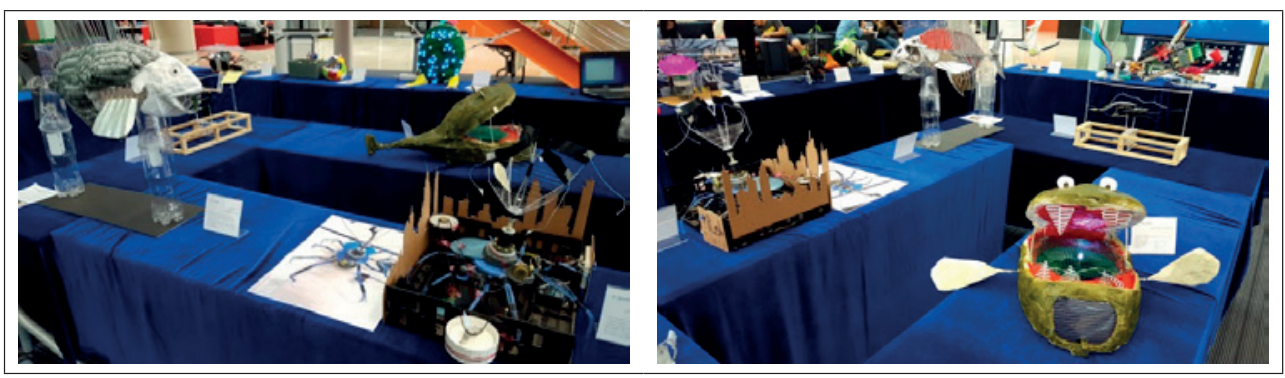




\section{Student responses to the studio work experience}

To determine the impact of the studio project, a post-class survey questionnaire was emailed to 144 students following the completion of coursework. In total, 33 completed questionnaires were returned (response rate: $22.9 \%)$. Respondents included 4 freshmen $(12.1 \%)$, 3 sophomores (9.0\%), 9 juniors (27.2\%) and 17 seniors (51.5\%), whose majors spanned the fields of engineering and business. The questionnaire comprised seven questions (Table 5).

Table 5. Post-class survey questionnaire (source: created by author)

\begin{tabular}{|l|l|}
\hline \multicolumn{1}{|c|}{ Category } & \multicolumn{1}{c|}{ Question } \\
\hline $\begin{array}{l}\text { Personal } \\
\text { relationship } \\
\text { to art }\end{array}$ & $\begin{array}{l}\text { Were you familiar with art before taking the course? Yes__ No__lain the reason for your answer. } \\
\text { Expla }\end{array}$ \\
\hline $\begin{array}{l}\text { Reasons for } \\
\text { taking the } \\
\text { course }\end{array}$ & $\begin{array}{l}\text { At the time of registering for the course, what was your main reason for selecting } \\
\text { the course? (Multiple selections are allowed.) } \\
\text { - Personal interest in art } \\
\text { - Suitability of course structure and the content } \\
\text { - To satisfy minimum credit requirement for graduation } \\
\text { - Other (Please explain) _ _ }\end{array}$ \\
\hline $\begin{array}{l}\text { Recognised } \\
\text { role and } \\
\text { meaning of art }\end{array}$ & $\begin{array}{l}\text { What was the recognised role and meaning of art during the course in general? } \\
\text { What was the role and meaning of art during the studio project development? }\end{array}$ \\
\hline $\begin{array}{l}\text { Meaningful } \\
\text { experience } \\
\text { during the } \\
\text { studio project }\end{array}$ & $\begin{array}{l}\text { Did you have any particularly meaningful experience while working on the } \\
\text { project? } \\
\text { What would you do if you had been given more time to work on the project? }\end{array}$ \\
\hline $\begin{array}{l}\text { Views on } \\
\text { the course } \\
\text { experience }\end{array}$ & $\begin{array}{l}\text { How might your course experience contribute to your future } \\
\text { (e.g. in terms of campus life, your major, your career path)? }\end{array}$ \\
\hline
\end{tabular}

The following section reviews the outcomes in each category, along with some noteworthy perspectives extracted from the students' responses to their studio work experience. There follows a discussion of art's potential role in promoting student creative engagement in interdisciplinary learning contexts.

\subsection{Personal relationship to art}

Although those students who responded to the survey request presumably had a stronger interest in art than those who did not respond, a majority of the respondents described themselves as unfamiliar with art before taking the course. Among those who returned the survey, 26 students (78.8\%) answered "No" when asked if they had a personal relationship with art while just 7 students $(21.2 \%)$ saw themselves as closely involved in art. The reasons for their distance from art were various and included the uncertain nature of art as a domain of knowledge, a belief that art is not useful, low interest, limited experience, little opportunity to get involved and lack of talent. Comments included the following: "I couldn't find anything special in my life related to art"; "I had neither reason nor time to think about art"; "Art doesn't square with me because it often shows no clear answers"; and "I thought of art as belonging to a different world". 
On the other hand, those who indicated that they were closely involved in art reported having participated in diverse activities related to art, craft, design or music. Some liked to visit museums or make things such as origami while others enjoyed playing musical instruments or going to live performances. Besides, there was one student referring to his keen sense of art appreciation as a supportive reason. A comparison of these data with the responses made to later questions revealed the positive impact of the course work experience in changing these students' perceptions; in particular, most of those who had a sense of distance from art at the beginning of the course appeared by the end to have developed a sufficiently personal relationship to art to be willing to participate in the survey and share their personal experiences.

\subsection{Reasons for taking the course}

The various reasons given by the students for taking the course were as follows: personal interest in art (42.3\%); suitability of course structure and the content (19.2\%); to satisfy minimum credit requirement for graduation (25.0\%); recommendations from class attendees in previous semesters (11.5\%); and other (e.g. to challenge my preconceptions about art) (1.9\%). The fact that the highest proportion of students referred to their "personal interest in art" indicates that the artistic component of the course was valued by a significant number of students who viewed the class as an opportunity to learn about the world of art. Their comments included the following. "As an engineering student, I would like to see what I could learn from art"; "I had the expectation of improving my craftsmanship"; "I wanted to make something similar to those works I'd seen in the exhibitions from this course in previous semesters"; "Although I had not been involved in art before, I wanted to get to know about art and expected to have some meaningful experience during this course". These declared expectations suggest that most of these students wished to broaden their view of art.

\subsection{Recognised role and meaning of art}

Responses to the question about the recognised role of art during the course included the following: as a medium that connects things; as an opportunity to develop thinking; as an effective method of expressing personal ideas; as a medium for delivering messages; as a means of bringing people together; and as a site for exchanging ideas. The respondents reported that it was meaningful to see how art contributes to the creation of new ideas, the enrichment of culture and the promotion of creativity. In describing the value of their experience, a few students noted that class discussions on diverse aspects of art enabled them to become more open-minded and to appreciate different perspectives.

Comments confirming that the class helped them to acknowledge more diverse viewpoints, meanings and expressions included the following. "The meaning of art seems to be the action of making something and giving meaning to it"; "I think art is an opportunity to learn different points of view"; "It was interesting to find that art supports so many different ways of interpreting and constructing ideas. I was surprised to see that all ideas were acceptable because they were based on compelling reasons"; "From the study of light art, I realised that light can be an interesting material for creating art"; "I found it interesting that there 
were many ways to develop ideas and forms"; "I didn't know that meaning could be changed by the situation or the context, but in fact when and where art is shown can influence how viewers interpret its meaning".

A number of students commented that the divergent nature of artistic inquiry was both difficult and an exciting challenge for them as engineering majors who were accustomed to more structured inquiry grounded in preset rules and definite answers. The comments seem to confirm the participants' recognition of the gulf between scientific and artistic inquiry.

\subsection{Meaningful experience during the studio project}

Experiences that students counted as meaningful in the studio project included close observation, productive communication and collaboration and developing ideas into high-quality products. In particular, many of the respondents appreciated the experience of developing ideas and solving problems using their scientific knowledge and the new possibilities afforded by working with others from different academic backgrounds. Their comments included the following. "I recognised the importance of interdisciplinary projects in exchanging ideas based on the diverse viewpoints of our group members specialising in different areas, and in how we achieved better or unexpected solutions when those ideas were brought together"; "I was interested in how a form of life was created by applying our scientific knowledge. This project also made us consider scientific issues and mechanical movement from an unusual viewpoint"; "While we may not have had enough artistic sense as individuals, I came to see our potential. We could do something meaningful when we worked together, using our own knowledge across different areas of expertise". These responses confirm the positive impact of interdisciplinary learning contexts in broadening students' thinking, which aligns with the evidence from previous studies (Curtis et al., 2012; Jacobson et al., 2016).

In relation to the effectiveness of the project structure, the students' responses indicated the particular importance of the four tasks assigned to help them to develop group works. Several students responded that the first two tasks - "Invent a creature and give it a role based on relevant scientific information" and "Imagine the life of the creature and give it a backstory" - raised their environmental awareness and sensitivity and helped them to look at environmental issues in relation to the sociocultural context. Some noted that these tasks led them to see an organism not only as a mechanical system but as an ecological system powered by a sustainable source of energy. As one student majoring in materials science and engineering noted, "The process of creating a form of life and developing its backstory piqued my interest. It is remarkable that, through a series of group discussions and based on the backstory we created, we figured out ways of transferring our eco-friendly concept into an actual lifeform mechanism. As a person studying materials science and engineering, finding energy-efficient materials that could deliver thermal energy without damage motivated me".

A student majoring in mechanical engineering wrote: "In developing a group project in connection with the air pollution and fine dust problems that have emerged as critical social issues in recent years, I came to recognise the importance of considering air pollution when fabricating engines (which I have studied in mechanical engineering)". 
Another stated: "It was difficult to make something that would solve social problems, but developing ideas connected to diverse social issues was rewarding. It made me think; I should not focus only on technical development but also on its social impact".

These responses imply that the assigned tasks provided opportunities to look at environmental problems within their broader sociocultural context, and to realise the power of art to reach people in ways that differ from science (Hoffman Davis, 2008; Inwood, 2008).

With regard to the more practical third and fourth tasks - "Include some parts of discarded household appliances in your group work" and "Imagine the creature's movement and consider ways of realising it" - students reported that these tasks led them to integrate their scientific knowledge in more practical ways. Table 6 presents two organisms: "Frog" collects and digests the algae living in the area suffering from heavy algal blooms whereas "Metal Beetle" gathers the heavy-metal shavings from soils living in highly contaminated areas by rolling its magnetic ball.

Table 6. Use of discarded household appliances (source: created by author)
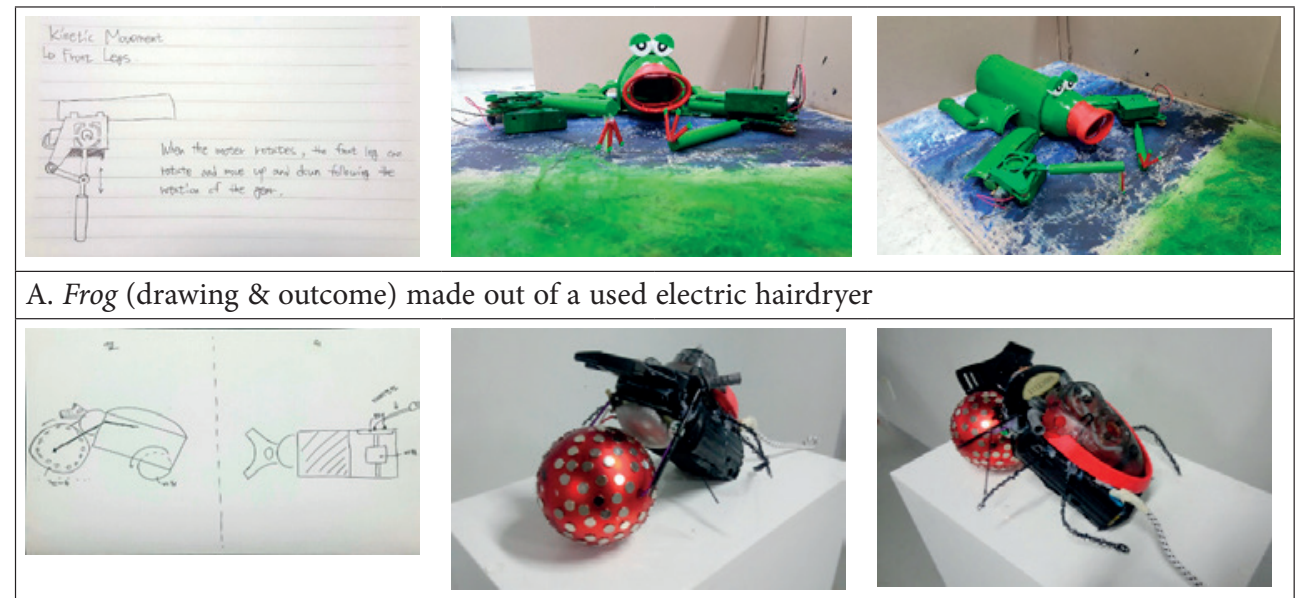

B. Metal Beetle (drawing \& outcome) made out of a discarded electric iron

Although not explicitly stated, the contribution of the assigned tasks to promoting creative engagement again seemed evident in the students' responses to the required materials and tasks. As for the material, one commented, "It was interesting to see that works of art can be made out of used household appliances and mundane materials readily found in our daily life". Responses reflecting some interests in the kinetic component included the following: "The technical challenges faced during project development meant that we put more effort into realising the mechanical movement in a more professional way"; "I was interested in the part where our group tried to figure out the basic principle of the mechanical motion of the device. We focused on how the ball turned on LED lights as it rolled forward, acting as on-off switches between two separate wires". More intensive discussions and collaborations among students were observed while working on these practical tasks. 


\section{Potential role of art in promoting creative engagement}

This analytical review of the project development serves to identify a number of factors that encouraged creative engagement with ecological issues, including the challenging tasks, the integrated elements, the collaborative process and the project's inclusive structures, which exposed students to the full range of studio work experiences. In general, the groups' reflections on the final studio work experience indicated considerable changes in these students' perceptions of art. In particular, the potential of "art as an integrating vehicle" in the context of combined inquiry-based learning is apparent in the diverse lines of inquiry pursued by groups in approaching the given environmental issues. The group arrangement of mixing students from diverse disciplinary backgrounds was proven to encourage more intensive collaboration among students (Efland, 2002). Within this interdisciplinary learning context, art served as an integrating vehicle by encouraging students to connect scientific problems to sociocultural issues, bringing together ideas from different domains of knowledge and integrating them in a dynamic process of "shaping forms to create expressive content" (Eisner, 2002, p. 81). In terms of the educational value of a floating learning space that demands more complicated and flexible thinking (Efland, 1995), this integrated art education learning context seems especially beneficial for engineering students who are used to a more structured learning environment (Bequette, J. W., Bequette, M. B., 2012; Hoffman Davis, 2008; Jacobson et al., 2016; Root-Bernstein, R., Root-Bernstein, M. 1999).

In demonstrating how tasks that are at once compelling and socially and personally relevant can increase students' interest and engagement, this group project confirms the potential of such challenging learning environments. Students' creative engagement with ecological issues increased markedly when they searched for ways to meet challenging requirements to use relevant scientific information and discarded household appliances to create forms of life that would contribute to environmental sustainability. Additionally, the level of participant satisfaction appeared to increase considerably when the end products of the group projects were exhibited in a public space. This observation reinforces the intrinsic quality of art: what we gain from a tangible creation is a unique experience that art can offer (Eisner, 2002; Hoffman Davis, 2008). Jessica Hoffman Davis noted that "Unlike other subjects, the arts allow [students] to create something new of their own invention that was not there before it was created" (2008, p. 51). In having their work viewed by others, students also recognised the value of art in facilitating social interactions and providing a space for the exchange of ideas (Curtis et al., 2012; Efland, 2002).

The changes in student perceptions of the relationship between science and art became clearer as the studio project developed, as ecological issues led them to explore both conceptual and practical connections between the two disciplines. In particular, their response to the task confirmed art's potential role in raising awareness of and increasing engagement with environmental concepts and issues as noted in earlier studies (Blandy \& Hoffman, 1993; Bowers, 1993; Graham, 2007). The findings have implications for environmental education programmes that emphasise scientific knowledge of environmental systems (Gurevitz, 2000; Jacobson et al., 2016) in that the ecological art project can offer "a dynamic way to increase the power and relevancy of learning about the environment by providing an alternative means of 
furthering learners' ecological literacy" (Inwood, 2008, p. 30). In fact, such dynamic practices promoted in the interdisciplinary context are more visibly observed in diverse collaborative practices of contemporary artists working in ecological realm (Spaid, 2002). Rosenthal (2003) viewed that the multidisciplinary nature of such art practices illuminates the potential role of art to become a venue for integrating disciplines and promote systemic thinking in ecology.

\section{Conclusions}

This study, as it highlights the educational value of comprehensive programs integrating arts into non-arts disciplines, provides implications for practitioners who seek ways to promote a holistic understanding of the world by going beyond narrow disciplinary paradigms (Clark \& Button, 2011; Curtis et al., 2012; Jacobson et al., 2016). It also can be seen as a response to "the important role of academic leadership in promoting awareness of, and implementing strategies for, arts integration" (Diaz \& McKenna, 2017, p. 11). As an exemplary case of integrated curriculum development in higher education demonstrating art's potential in promoting creative engagement with ecological issues, this study contributes to ongoing research seeking more holistic approaches that incorporate multiple perspectives from across the disciplines.

\section{Acknowledgements}

This work was supported by the National Research Foundation of Korea (NRF) Grant funded by the Korean Government (MSIP) (No. NRF-2015R1A5A7037825).

\section{References}

Bequette, J. W., \& Bequette, M. B. (2012). A place for art and design education in the STEM Conversation. Art Education, 65(2), 40-47.

Bertling, J. G. (2015). The art of empathy: A mixed methods case study of a critical place-based art education program. International Journal of Education \& the Arts. Retrieved from http://www.ijea.org/v16n13/ v16n13.pdf

Blandy, D., \& Hoffman, E. (1993). Toward an art education of place. Studies in Art Education, 35(1), 22-33. https://doi.org/10.2307/1320835

Bowers, Ch. A. (1993). Critical essays on education, modernity, and the recovery of the ecological imperative. New York: Teachers College Press.

Brady, E. (1998). Imagination and the aesthetic appreciation of nature. The Journal of Aesthetics and Art Criticism, 56(2), 139-147. https://doi.org/10.2307/432252

Clark, B., \& Button, Ch. (2011). Sustainability transdisciplinary education model: Interface of Arts, Science, and Community (STEM). International Journal of Sustainability in Higher Education, 12(1), 41-54. https://doi.org/10.1108/14676371111098294

Curtis, D. J., Reid, N., \& Ballard, G. (2012). Communicating ecology through art: what scientists think. Ecology and Society. https://doi.org/10.5751/ES-04670-170203

Diaz, G., \& McKenna, M. B. (Eds.). (2017). Preparing educators for arts integration: Placing creativity at the center of learning. New York: Teachers College Press. 
Efland, A. D. (1995). The spiral and the lattice: Changes in cognitive learning theory with implications for art education. Studies in Art Education, 36(3), 134-153. https://doi.org/10.2307/1320905

Efland, A. D. (2002). Art and cognition: Integrating the visual arts in the curriculum. New York and London: Teachers College Press.

Eisner, E. W. (2002). The arts and the creation of mind. New Haven, CT: Yale University Press.

Erzen, J. (2005). An ecological approach to art education: environmental aesthetics. International Journal of Education through Art, 1(2), 179-186. https://doi.org/10.1386/etar.1.2.179/1

Graham, M. A. (2007). Art, ecology and art education: Locating art education in a critical place-based pedagogy. Studies in Art Education, 48(4), 375-391.

Gurevitz, R. (2000). Affective approaches to environmental education: Going beyond the imagined worlds of childhood?. Ethics, Place \& Environment, 3(3), 253-268. https://doi.org/10.1080/713665905

Hadzigeorgiou, Y., \& Skoumios, M. (2013). The development of environmental awareness through school science: Problems and possibilities. International Journal of Environmental \& Science Education, 8: 405-426.

Hoffman Davis, J. (2008). Why our schools need the arts. New York and London: Teachers College Press.

Hollis, C. L. (1997). On developing an art and ecology curriculum. Art Education, 50(6), 21-24. https://doi.org/10.2307/3193684

Hudson, S. J. (2001). Challenges for environmental education: Issues and ideas for the 21st century: Environmental education, a vital component of efforts to solve environmental problems, must stay relevant to the needs and interests of the community and yet constantly adapt to the rapidly changing social and technological landscape. BioScience, 51(4), 283-288.

https://doi.org/10.1641/0006-3568(2001)051[0283:CFEEIA]2.0.CO;2

Yang, Ch.-P. (2015). Education for appreciating environment - An example of curriculum design of natural aesthetic education in Taiwan. International Education Studies, 8(5), 88-100. https://doi.org/10.5539/ies.v8n5p88

Inwood, H. (2010). Shades of green: Growing environmentalism through art education. Art Education, 63(6), 33-38.

Inwood, H. J. (2008). At the crossroads: Situating place-based art education. Canadian Journal of Environmental Education, 13(1), 29-41.

Jacobson, S. K., Seavey, J. R., \& Mueller, R. C. (2016). Integrated science and art education for creative climate change communication. Ecology and Society. Retrieved from https://www.ecologyandsociety.org/vol21/iss3/art30/. https://doi.org/10.5751/ES-08626-210330

juxtapoz.com. (2015). U-Ram Choe's Kinetic Sculptures. Retrieved from https://www.juxtapoz.com/news/ sculpture/u-ram-choe-s-kinetic-sculptures/

Matilsky, B. C. (1992). Fragile ecologies: contemporary artists' interpretations and solutions. New York: Rizzoli.

Neperud, R. W. (1997). Art, ecology and art education: Practices \& linkages. Art Education, 50(6), 14-20. https://doi.org/10.2307/3193683

Root-Bernstein, R., \& Root-Bernstein, M. (1999). Sparks of genius: The 13 thinking tools of the world's most creative people. New York: Mariner Books.

Rosenthal, A. T. (2003). Teaching systems thinking and practice through environmental art. Ethics \& the Environment, 8(1), 153-168. https://doi.org/10.1353/een.2003.0013

Savva, A., Trimis, E., \& Zachariou, A. (2004). Exploring the links between visual arts and environmental education: Experiences of teachers participating in an in-service training programme. The International Journal of Art \& Design Education, 23(3), 246-255. https://doi.org/10.1111/j.1476-8070.2004.00404.x

Song, Y. I. K. (2008). Exploring connections between environmental education and ecological public art. Childhood Education, 85(1), 13-19. https://doi.org/10.1080/00094056.2008.10523051 
Song, Y. I. K. (2012). Crossroads of public art, nature and environmental education. Environmental Education Research, 18(6), 797-813. https://doi.org/10.1080/13504622.2012.670208

Spaid, S. (2002). Ecovention: Current art to transform ecologies. Cincinnati, OH: The Contemporary Arts Center.

UNESCO. (2017). UNESCO and sustainable development goals. Retrieved from http://en.unesco.org/sdgs

Walker, H. (2001). Interviewing local artists: A curriculum resources in art teaching. Studies in Art Education, 42(3), 249-265. https://doi.org/10.2307/1321040

\title{
KŪRYBINIS EKOLOGINIŲ PROBLEMŲ SPRENDIMAS: DARBO STUDIJOJE PATIRTIS TARPDISCIPLININIO MOKYMO KONTEKSTE
}

\author{
Kyong-Mi PAEK \\ Santrauka
}

Šiuolaikinių aplinkos keliamų problemų kompleksiškumas reikalauja labiau holistinio ir tarpdisciplininio atsako. Vis dèlto, nepaisant plačiai vyraujančio požiūrio, kad tarpdisciplininis mokymas teikia naudos išsilavinimo požiūriu, šiais klausimais aktualios literatūros apžvalga atskleidžia, jog tokių požiūrių tyrinejjimas išlieka gana ribotas ir turi nedidelę įtaką nusistovèjusioms pedagoginèms praktikoms. Šiuo straipsniu siekiama prisidèti prie tarpdisciplininių požiūrių tyrinèjimo, praplečiant empirinị supratimą, kaip, atsižvelgiant ị ekologijos problemas, menas gali paskatinti kūrybinị sprendimą. Iš pradžių aprašomas bendradarbiavimu pagrịstas ekologinio meno projekto, ịtraukusio inžinerijos studentus, procesas ir jo rezultatai; paskui straipsnyje apžvelgiami kai kurie įdomūs duomenys, gauti atlikus poprojektinę apklausą apie studentų darbo studijoje patirtị. Daromos išvados, kad vyksta diskusija apie galimą meno vaidmenị skatinant kūrybinius sprendimus tarpdisciplininio mokymo kontekste.

Reikšminiai žodžiai: bendradarbiavimu pagrịstas meno projektas, kūrybinis sprendimas, mokymo programų rengimas, ekologijos problemos, tarpdisciplininis mokymas, specialisto praktiko atliekamas tyrimas. 